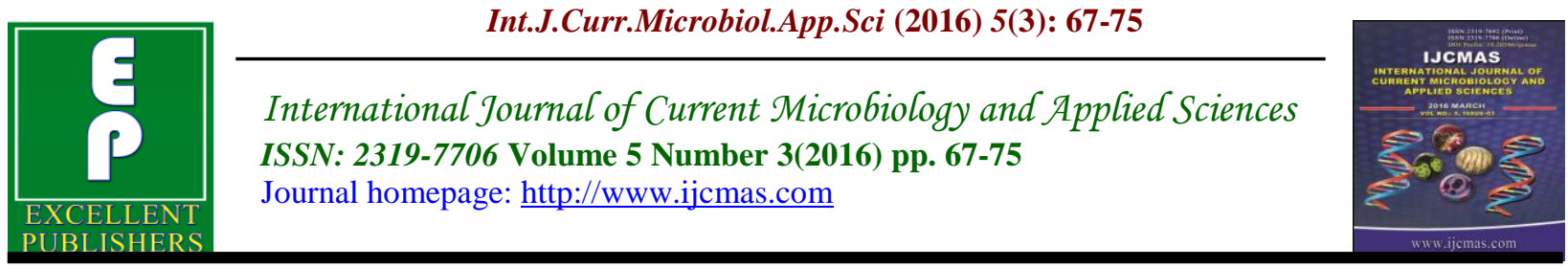

Original Research Article

http://dx.doi.org/10.20546/ijcmas.2016.503.010

\title{
Studies on Growth Response of Fungi Using Antibiotic Ointments
}

\author{
R. Sugumar and Anandha Raj* \\ Department of Microbiology, M. R. Government Arts College, Mannargudi - 614 001, India \\ *Corresponding author
}

\begin{tabular}{|c|c|}
\hline & A B S T R A C T \\
\hline $\begin{array}{l}\text { Ke y w o r d s } \\
\text { Xenobiotics, } \\
\text { Three drugs, } \\
\text { Fungi Diversity, } \\
\text { Antibiotic } \\
\text { ointments. }\end{array}$ & \multirow{3}{*}{$\begin{array}{l}\text { Xenobiotics refers to both organic and inorganic substances that mimic } \\
\text { natural biochemicals that are essential for life. They may be persistent and } \\
\text { often toxic to life. Pharmaceutical industries generate a large amount of } \\
\text { waste during manufacturing, housekeeping and maintenance operations. } \\
\text { Hence, the present study was attempted to study the impact of these residues } \\
\text { in the soil on fungal diversity. The three drugs that were identified were } \\
\text { Fungitop F and Fungi top. Results show that the soil recorded very less } \\
\text { fungal diversity and all the species of fungi isolated showed decreased } \\
\text { growth. Among the three drugs, fungi top inhibited the growth the most } \\
\text { among the different fungi. A. flavus had the most inhibitive effect. }\end{array}$} \\
\hline Article Info & \\
\hline $\begin{array}{l}\text { Accepted: } \\
\text { 07 February } 2016 \\
\text { Available Online: } \\
\text { 10, March } 2016\end{array}$ & \\
\hline
\end{tabular}

\section{Introduction}

Xenobiotics are known dangerous pollutants which include both inorganic elements like heavy metals, metalloids and man-made organic compounds such as pesticides, surfactants, industrial solvents, fragrances, flavours and pharmaceuticals as well as endocrine disrupters. It has been estimated that over 70,000 xenobiotics may potentially be hazardous for humans and/or ecosystems. The presence of xenobiotics in surface as well as underground waters have become a problem for urban water supply as treatment systems were originally not designed to solve xenobiotic problems (Alexander, 1965, 1980; Skladany and Metting, 1992; Ankumah et al., 1995).
Pharmaceutical plants also generate a large amount of wastes during manufacturing, housekeeping and maintenance operations. Worldwide detection of waste pharmaceuticals in the environment causes risks associated with their introduction into wildlife habitats and is becoming a serious issue for both regulators and the pharmaceutical industry (Crane et al., 2006). Although different classes of pharmaceuticals are used in human and veterinary medicine, only a few are of environmental importance because of their consumption volumes, toxicity, and persistence in the environment. 
Pharmaceuticals in the aquatic environment have been reported in rivers, sewage, streams, seawater, ground water, and drinking water. Measurable concentrations are usually low ranging from $\mathrm{mg} / \mathrm{l}$ to $\mu \mathrm{g} / \mathrm{l}$ (Fent et al., 2006) yet may be high close to the point of input, particularly for veterinary medicines used in aquaculture where concentrations may reach the low to medium $\mu \mathrm{g} / \mathrm{l}$ range in surface water (Boxall et al., 2004). Hence monitoring of pharmaceutical products in the surface water and/or ground water is essential. In addition, pharmaceutical products reach the environment primarily through usage or inappropriate disposal. Various production facilities were found to be sources of much higher environmental concentrations than those caused by the usage of drugs (Larsson et al., 2007). Hence in the present study, some drugs that were found at the site of waste disposal at Thanjavur were collected and studied for their impacts on soil fungi, which are key players in any ecosystem for maintaining the fertility by recycling of nutrients.

\section{Materials and Methods}

\section{Isolation of Fungi}

Drug spilled surface soil samples were collected aseptically from Municipal waste disposal site at Musiri and transported to the laboratory. The samples were serially diluted and plated on 2\% PDA Medium (supplemented with streptopenicillin antibiotic solution $16 \mathrm{ml} / \mathrm{l})$. The plates were incubated at room temperature for a week. The fungal colonies were then transferred on to PDA plates for raising pure cultures. They were identified referring standard manuals (Raper and Thom, 1949; Von Arx, 1974; Ainsworth et al., 1973; Raper and Fennell, 1965; Ellis, 1976) based on the morphological characters.

\section{Analysis of Physicochemical Characteristics of the Soil}

Moisture content was estimated by finding the difference in weight of known quantity of soil before and after drying in a hot air oven at $60^{\circ} \mathrm{C}$ for 6 hours. Soil samples after removing the debris were suspended in distilled water $(1: 2 \mathrm{w} / \mathrm{v})$ and allowed to settle down. The $\mathrm{pH}$ of the suspension was read using a $\mathrm{pH}$ meter (Systronics, India). Electrical conductivity of soil was determined in the water filtrate using Conductivity Bridge as described by Jackson (1973) while cation Exchange Capacity (CEC) of the soil was determined by using $1 \mathrm{~N}$ ammonium acetate solution as described by Jackson (1973).

Organic carbon content was determined by adopting chromic acid wet digestion method (Walkley and Black, 1934), while available nitrogen by alkaline permanganate method (Subbiah and Asija, 1956) and available phosphorus by Brayl method (Bray and Kutz, 1945). Available potassium was extracted from soil with neutral $1 \mathrm{~N}$ ammonium acetate (1:5) and the potassium content in the extract was determined by using flame photometer (Standfold and English, 1949); calcium (Neutral $1 \mathrm{~N} \mathrm{NH}_{4}$ OAC extractable 1:5) was extracted with neutral $1 \mathrm{~N}$ ammonium acetate and the available calcium in the extract was determined by Versenate method (Jackson, 1973). Available micronutrients such as $\mathrm{Zn}$, $\mathrm{Cu}$ and $\mathrm{Mn}$ were determined in the diethylene triarnine pentaacetic extract of soil using Perkin-Elmer model 2280 Atomic Absorption Spectrophotometer (Lindsay and Norvell, 1978). Other nutrients such as magnesium, sodium and available iron were analysed following the method of Barnes (1959) and Muthuvel and Udayasoorian (1999). 


\section{Selection of Drugs}

The drugs that were disposed along with other municipal waste were collected and identified. They were procured from druggist in required quantity to do the experiments. The commercial names of these drugs are:

i) Fungitop - F: A Glucocorticoid derivative used in the treatment of various skin disorders.

ii) Diprolite: It inhibits the growth of fungi and bacteria which cause skin infections.

iii) Fungitop: It is used in the treatment of inflammation in ear, nose and eye disorders.

\section{Impact of Drugs on the Growth of Fungi}

Potato Dextrose Agar broth was prepared and $20 \mathrm{ml}$ of the broth was dispersed in each of $50 \mathrm{ml}$ conical flasks and sterilized in an autoclave. Streptopenicillin, an antibiotic solution was added to this at the concentration mentioned earlier. Single and double doses of the drugs were allowed to dissolve in $20 \mathrm{ml}$ of the PD Broth by shaking constantly. Fungi were inoculated using sterile forceps to these flasks aseptically in a Laminar Air Flow (LAF) Cabinet.

The culture flasks were incubated at room temperature for a week, allowing the formation of complete mycelial mat on the surface of the broth. After incubation, the broth was drained from the flask and the weights taken [weights of flasks with mycelium (A)]. The flasks were then autoclaved, the mycelial mats were discarded and again the weights were measured [weights of flasks without mycelium (B)]. The drained broth were also sterilised and discarded.
By subtracting the values of B from A, the mycelial biomass (Wet weight) was calculated and the values were accounted as a measure for the growth of fungi.

\section{Combined Impact of $\mathrm{pH}$ and Drug on the Growth of Fungi}

To assay the combined impact of $\mathrm{pH}$ and drug on the growth of fungi, single drugs were dissolved in $20 \mathrm{ml}$ of autoclaved PD Broth (later incorporated with antibiotic solution) at $50 \mathrm{ml}$ in a conical flask and the broth was adjusted to $\mathrm{pH} \mathrm{4,7}$ and 9 using O.1N NaOH (to increase the $\mathrm{pH}$ ) and O.IN $\mathrm{HCL}$ (to decrease the $\mathrm{pH}$ ). The flasks were inoculated with the growing tip of the fungal mycelia and incubated at room temperature $\left(27 \pm 2^{\circ} \mathrm{C}\right)$ in a culture rack. After a week, the mycelial biomass was calculated as described earlier. The experiment was repeated once again and the average value of both the experiment was accounted.

\section{Results and Discussion}

Dilution plating of soils collected from the Municipal waste at Musiri, resulted in the yielding of only 4 species of fungi. Their mean population density was $61 \times 10^{2}$ $\mathrm{CFU} / \mathrm{g}$ of soil. The percentage contribution of the individual species in relation to the total fungal population was: Aspergillus flavus (20.5\%), A. oryzae (17.6\%) and A. niger $(35.5 \%)$.

\section{Physiochemical Characteristics}

Physiochemical characteristics of the soil samples analysed from these sites are presented in Table.

\section{Fungitop (Table 2)}

As evident from the table, in control, the growth of A. flavus was maximum recording $4.5 \mathrm{~g}$ of wet mycetial biomass. However, 
with single dose drug, the growth recorded was only $33 \%$ when compared to the control while in double dose concentration, there was only $15.5 \%$ of growth when compared to the control.

With regard to $A$. oryzae, the control recorded a growth of $4.9 \mathrm{~g}$ of wet mycelia biomass which decreased to $28.8 \%$ in single unit and $13.0 \%$ in double unit concentration.

While A. niger recorded a growth of $5.3 \mathrm{~g}$ of wet mycelial biomass in the control, there was only a growth of $22.6 \%$ and $15.0 \%$ in single and double unit concentrations respectively.

In terms of growth, among the three species, the maximum reduction in growth was recorded by $A$. flavus.

\section{Diprolite (Table 3)}

As seen from the table, A. flavus recorded a growth of $4.5 \mathrm{~g}$ of wet mycelial biomass in control. While the growth was $40 \%$ of the control in single unit concentration, it further reduced to $22.2 \%$ of the control when exposed to double unit concentration.

In $A$. oryzae while the growth recorded in the control medium was $4.9 \mathrm{~g}$ of wet mycelial biomass in single unit concentration of the drug, growth was found to decrease by $18.4 \%$ of the control and in double unit concentration it further decreased to $8.16 \%$ of the control.

In the case of $A$. niger, while the control recorded a growth of $5.3 \mathrm{~g}$ of wet mycelial biomass, in single unit concentration growth decreased to $17 \%$ while in double unit concentration growth further decreased to $7 \%$ when compared to the control. Thus all the three species showed growth, but it varied. Among the three, the maximum affected species was again $A$. flavus.

\section{Fungitop (Table 4)}

A perusal of the table reveals that in $A$. flavus, the control recorded a growth of 4.5 $\mathrm{g}$ of wet mycelial biomass while in single unit concentration growth decreased by $26.6 \%$ and in double unit concentration growth decreased to $11.1 \%$ when compared to the control.

While the growth of $A$. oryzae in the control medium was $4.9 \mathrm{~g}$ of wet mycelial biomass, in single unit concentration growth reduced by $20.4 \%$ and in double unit concentration growth decreased to $14.3 \%$ when compared to the control.

In $A$. niger, while the control medium registered a growth of $5.3 \mathrm{~g}$ of wet mycelial biomass, in single unit concentration, growth decreased by $24.5 \%$ and in double unit concentration growth decreased to $13.2 \%$ when compared to the control.

Thus even though all the three species recorded growth, the species which was affected the most was A. flavus. Further, among the three xenobiotics, fungitop appeared to be the most damaging as growth was drastically reduced when compared with the other two.

The growth of the fungi in different $\mathrm{pH}$ supplemented with Miconazole Nitrate and Fluocinolone Acetate Cream are presented in Table-5. As evident from the table, among the three $\mathrm{pH}$, growth appeared to be highest at $\mathrm{pH} 4$ for Aspergillus flavus and $A$. niger while it was $\mathrm{pH} 7$ for $A$. oryzae. Thus, even though all the species grew at all $\mathrm{pH}$, their growth rate differed in different $\mathrm{pH}$. 
Table- 6 records the growth of fungi in different $\mathrm{pH}$ supplemented with beclomethasone dipropionate clotrimazole and neomycin cream. It is clear from the table that growth was highest at $\mathrm{pH} 4$ for $A$. flavus and $A$. niger while it was at $\mathrm{pH} 7$ for A. oryzae.

Table.1 Physiochemical Characteristics of the Sampling Soils

\begin{tabular}{|c|l|c|c|}
\hline S. No. & \multicolumn{1}{|c|}{ Name of the Parameter } & Sampling I & Sampling II \\
\hline 1. & $\mathrm{pH}$ & 7.89 & 7.46 \\
\hline 2. & Electrical conductivity $\left(\mathrm{dsm}^{-1}\right)$ & 0.51 & 0.64 \\
\hline 3. & Organic Carbon (\%) & 0.26 & 0.31 \\
\hline 4. & Organic Matter (\%) & 0.52 & 0.62 \\
\hline 5. & Available Nitrogen (kg/ac) & 126.20 & 136.80 \\
\hline 6. & Available Phosphorus (kg/ac) & 4.62 & 4.16 \\
\hline 7. & Available Potassium (kg/ac) & 148.00 & 0.96 \\
\hline 8. & Available Zinc (ppm) & 0.59 & 0.75 \\
\hline 9. & Available Copper (ppm) & 4.06 & 4.15 \\
\hline 10. & Available Iron (ppm) & 2.06 & 2.13 \\
\hline 11. & Available Manganese (ppm) & & \\
\hline
\end{tabular}

Table.2 Growth (Mycelial Biomass) of Fungi in Different Concentrations of Miconazole Nitrate and Fluocinolone Acetonide Cream

\begin{tabular}{|c|c|c|c|c|}
\hline Fungi & Volume of Drug & $\begin{array}{c}\text { Concentration of drug / } 20 \mathrm{ml} \\
\text { (PhAC's) }\end{array}$ & $\begin{array}{c}\text { Mycelial } \\
\text { biomass } \\
\text { (g) }\end{array}$ & $\begin{array}{l}\% \text { of } \\
\text { growth }\end{array}$ \\
\hline \multirow{3}{*}{$\begin{array}{l}\text { Aspergillus } \\
\text { flavus }\end{array}$} & $300 \mathrm{mg}$ cream & Mi Ni: 6 mg; Fl Ac: 0.03 mg & 1.5 & 33.3 \\
\hline & $500 \mathrm{mg}$ cream & Mi Ni: 10 mg; Fl Ac: 0.06 mg & 0.7 & 15.5 \\
\hline & & 0 & 4.5 & 100.0 \\
\hline \multirow[t]{3}{*}{ A. oryzae } & $300 \mathrm{mg}$ cream & Mi Ni: 6 mg; Fl Ac: 0.03 mg & 1.3 & 28.8 \\
\hline & $500 \mathrm{mg}$ cream & Mi Ni: 10 mg; Fl Ac: 0.06 mg & 0.6 & 13.0 \\
\hline & & 0 & 4.9 & 100.0 \\
\hline \multirow[t]{3}{*}{ A. niger } & $300 \mathrm{mg}$ cream & Mi Ni: 6 mg; Fl Ac: 0.03 mg & 1.2 & 22.6 \\
\hline & $500 \mathrm{mg}$ cream & Mi Ni: 10 mg; Fl Ac: 0.06 mg & 0.8 & 15.0 \\
\hline & & 0 & 5.3 & 100.0 \\
\hline
\end{tabular}

Mi Ni: Miconazole Nitrate; Fl Ac: Fluocinolone Acetonide 
Table.3 Growth (Mycelial Biomass) of Fungi in Different Concentrations of Beclomethasone Dipropionate, Clotrimazole and Neomycin Sulphate Cream

\begin{tabular}{|c|c|c|c|c|}
\hline Fungi & $\begin{array}{l}\text { Volume of } \\
\text { Drug }\end{array}$ & $\begin{array}{c}\text { Concentration of drug / } 20 \mathrm{ml} \\
\text { (PhAC's) }\end{array}$ & $\begin{array}{c}\text { Mycelial } \\
\text { biomass } \\
\text { (g) }\end{array}$ & $\begin{array}{c}\% \text { of } \\
\text { growth }\end{array}$ \\
\hline \multirow[t]{3}{*}{$\begin{array}{l}\text { Aspergillus } \\
\text { flavus }\end{array}$} & $\begin{array}{l}300 \mathrm{mg} \\
\text { cream }\end{array}$ & $\begin{array}{l}\text { Be: } 0.075 \mathrm{mg} ; \mathrm{Cl}: 3 \mathrm{mg} \text {; } \\
\text { NeS: Trace; NB: } 1.5 \mathrm{mg} \text {; Ch: } 0.3 \mathrm{mg}\end{array}$ & 1.8 & 40.0 \\
\hline & $\begin{array}{l}500 \mathrm{mg} \\
\text { cream }\end{array}$ & $\begin{array}{l}\text { Be: } 0.125 \mathrm{mg} \text {; Cl: } 5 \mathrm{mg} \text {; } \\
\text { NeS: Trace; NB: } 2.5 \mathrm{mg} \text {; Ch: } 0.5 \mathrm{mg}\end{array}$ & 1.0 & 22.2 \\
\hline & & 0 & 4.5 & 100.0 \\
\hline \multirow[t]{3}{*}{ A. oryzae } & $\begin{array}{l}300 \mathrm{mg} \\
\text { cream }\end{array}$ & $\begin{array}{l}\text { Be: } 0.075 \mathrm{mg} \text {; Cl: } 3 \mathrm{mg} \text {; } \\
\text { NeS: Trace; NB: } 1.5 \mathrm{mg} \text {; Ch: } 0.3 \mathrm{mg}\end{array}$ & 0.9 & 18.4 \\
\hline & $\begin{array}{l}500 \mathrm{mg} \\
\text { cream }\end{array}$ & $\begin{array}{l}\text { Be: } 0.125 \mathrm{mg} ; \mathrm{Cl}: 5 \mathrm{mg} ; \\
\text { NeS: Trace; NB: } 2.5 \mathrm{mg} \text {; Ch: } 0.5 \mathrm{mg}\end{array}$ & 0.4 & 8.2 \\
\hline & & 0 & 4.9 & 100.0 \\
\hline \multirow[t]{3}{*}{ A. niger } & $\begin{array}{l}300 \mathrm{mg} \\
\text { cream }\end{array}$ & $\begin{array}{l}\text { Be: } 0.075 \mathrm{mg} ; \mathrm{Cl}: 3 \mathrm{mg} ; \\
\text { NeS: Trace; NB: } 1.5 \mathrm{mg} \text {; Ch: } 0.3 \mathrm{mg}\end{array}$ & 0.9 & 17.0 \\
\hline & $\begin{array}{l}500 \mathrm{mg} \\
\text { cream }\end{array}$ & $\begin{array}{l}\text { Be: } 0.125 \mathrm{mg} \text {; Cl: } 5 \mathrm{mg} \text {; } \\
\text { NeS: Trace; NB: } 2.5 \mathrm{mg} \text {; Ch: } 0.5 \mathrm{mg}\end{array}$ & 0.4 & 7.0 \\
\hline & & 0 & 5.3 & 100.0 \\
\hline $\begin{array}{l}\text { Beclome } \\
:\end{array}$ & $\begin{array}{l}\text { ne Dipropionate } \\
\text { Neomycin base }\end{array}$ & $\begin{array}{l}\text { Clotrimazole; NeS : } \\
\text { Chlorocresal (as preservative) }\end{array}$ & in Sulphate & m; \\
\hline
\end{tabular}

Table.4 Growth (Mycelial Biomass) of Fungi in Different Concentrations of Miconazole Nitrate Cream

\begin{tabular}{|c|c|c|c|c|}
\hline Fungi & $\begin{array}{l}\text { Volume of } \\
\text { Drug }\end{array}$ & 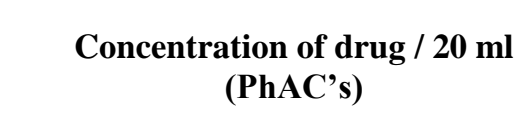 & $\begin{array}{c}\text { Mycelial } \\
\text { biomass } \\
\text { (g) }\end{array}$ & $\begin{array}{c}\% \text { of } \\
\text { growth }\end{array}$ \\
\hline \multirow{3}{*}{$\begin{array}{l}\text { Aspergillus } \\
\text { flavus }\end{array}$} & $300 \mathrm{mg}$ cream & Mi Ni: 6 mg & 1.2 & 26.6 \\
\hline & $500 \mathrm{mg}$ cream & Mi Ni: $10 \mathrm{mg}$ & 0.5 & 11.1 \\
\hline & & 0 & 4.5 & 100.0 \\
\hline \multirow[t]{3}{*}{ A. oryzae } & $300 \mathrm{mg}$ cream & Mi Ni: 6 mg & 1.0 & 20.4 \\
\hline & $500 \mathrm{mg}$ cream & Mi Ni: $10 \mathrm{mg}$ & 0.7 & 14.3 \\
\hline & & 0 & 4.9 & 100.0 \\
\hline \multirow[t]{3}{*}{ A. niger } & $300 \mathrm{mg}$ cream & Mi Ni: 6 mg & 1.3 & 24.5 \\
\hline & $500 \mathrm{mg}$ cream & Mi Ni: $10 \mathrm{mg}$ & 0.7 & 13.2 \\
\hline & & 0 & 5.3 & 100.0 \\
\hline
\end{tabular}


Table.5 Growth (Mycelial Biomass) of Fungi in Different Ph of the Medium Supplemented with Miconazole Nitrate and Fluocinolone Acetonide Cream

\begin{tabular}{|c|c|c|}
\hline Fungi & pH & Mycelial biomass (g) \\
\hline \multirow[t]{3}{*}{ Aspergillus flavus } & 4 & 2.0 \\
\hline & 7 & 1.8 \\
\hline & 9 & 1.4 \\
\hline \multirow[t]{3}{*}{ A. oryzae } & 4 & 1.0 \\
\hline & 7 & 1.3 \\
\hline & 9 & 0.4 \\
\hline \multirow[t]{3}{*}{ A. niger } & 4 & 1.3 \\
\hline & 7 & 1.2 \\
\hline & 9 & 0.6 \\
\hline
\end{tabular}

Table.6 Growth (Mycelial Biomass) of Fungi in Different pH of the Medium supplemented with Beclomethasone Dipropionate, Clotrimazole and Neomycin Sulphate Cream

\begin{tabular}{|l|c|c|}
\hline \multirow{4}{*}{ Fungi } & pH & Mycelial biomass (g) \\
\hline \multirow{3}{*}{ Aspergillus flavus } & 4 & 2.1 \\
\cline { 2 - 3 } & 7 & 1.8 \\
\cline { 2 - 3 } & 9 & 1.9 \\
\hline \multirow{3}{*}{ A. oryzae } & 4 & 0.8 \\
\cline { 2 - 3 } & 7 & 0.9 \\
\cline { 2 - 3 } & 9 & 0.4 \\
\hline \multirow{3}{*}{ A. niger } & 4 & 1.3 \\
\cline { 2 - 3 } & 7 & 0.9 \\
\cline { 2 - 3 } & 9 & 0.7 \\
\hline
\end{tabular}

Table.7 Growth (Mycelial Biomass) of Fungi in Different Ph of the Medium Supplemented with Miconazole Nitrate Cream

\begin{tabular}{|l|c|c|}
\hline \multicolumn{1}{|c|}{ Fungi } & $\mathbf{p H}$ & Mycelial biomass (g) \\
\hline \multirow{3}{*}{ Aspergillus flavus } & 4 & 1.4 \\
\cline { 2 - 3 } & 7 & 1.2 \\
\cline { 2 - 3 } & 9 & 1.0 \\
\hline \multirow{3}{*}{ A. oryzae } & 4 & 0.8 \\
\cline { 2 - 3 } & 7 & 1.0 \\
\cline { 2 - 3 } & 9 & 0.6 \\
\hline \multirow{2}{*}{ A. niger } & 4 & 1.5 \\
\cline { 2 - 3 } & 7 & 1.3 \\
\cline { 2 - 3 } & 9 & 1.0 \\
\hline
\end{tabular}


Table-7 records the growth of fungi in different $\mathrm{pH}$ supplemented with Miconazole nitrate cream. Here also, as seen earlier, $A$. flavus and $A$. niger recorded highest growth at $\mathrm{pH} 4$ while $A$. oryzae recorded highest growth at $\mathrm{pH} 7$. Thus, overall it is clear that growth takes place in all the $\mathrm{pH}$ but each species had their own preference to record their growth at a particular $\mathrm{pH}$. Further, growth decreased in all the medium containing xenobiotics when compared to the control.

The study revealed the existence of only 3 species of fungi with a mean population density of $58 \times 10^{-2} \mathrm{CFU} / \mathrm{g}$. The species diversity and population density recorded in the present study is comparatively less than in agricultural soils (Sivakami et al., 2015), coastal soils (Madhanraj et al., 2011) and even in the poor nutrient sand dune soils (Madhanraj et al., 2010; Upadhyay et al., 1978). However, the physiochemical characteristics of the soil showed values closer to the agricultural soil (Sivakami et al., 2015), especially those of the nutrient minerals. The nutrient contents were higher than the coastal soils and sand dune soils. In spite of this appreciable nutrient content, the soil where the drugs were disposed off contained less fungal density and diversity.

A drug-wise comparison reveals that Fungitop seems to be highly harmful to the soil fungal community as it decreased the growth and density at both single and double concentration of drugs tested.

In drug supplemented PD broth, different $\mathrm{pH}$ influenced the growth of the fungi in varying degrees. Fungitop-F was moderately utilized by $A$. flavus and $A$. niger in acidic $\mathrm{pH}$, while $A$. oryzae at alkaline $\mathrm{pH}$, as the $\mathrm{pH}$ values yielded also low mycelial biomass. Dirolite, however, supported the average growth of $A$. oryzae at $\mathrm{pH} 7$ and $A$. flavus and A. niger at $\mathrm{pH}$ 4. Fungitop also suppressed maximal growth of $A$. flavus, $A$. oryzae and $A$. niger at $\mathrm{pH} 7$ when compared to other $\mathrm{pH}$.

The growth of fungi analysed with three drugs such as Fungitop-F, Diprolite and Fungitop on Aspergillus flavus, A. oryzae and $A$. niger at different $\mathrm{pH}$ also revealed that growth does take place. However, each species recorded maximum growth at a specific $\mathrm{pH}$. Further, growth rate decreased in all the media containing xenobiotics even at different $\mathrm{pH}$.

\section{References}

Ainsworth, G.C., Sparrow, F.K., Sussman, A.S. 1973. The fungi - an advanced treatise: a taxonomic review with keys. In: Ascomycetes and fungi Imperfecti., Academic Press, New York., 4(A): 621.

Alexander, M. 1965. Persistence and biological reactions of pesticides in soils. Soil Sci. Society America Proceedings, 29: 1-7.

Alexander, M. 1980. Biodegradation of chemicals of environmental concern. Science, 211: 132-138.

Ankumah, R.O., Dick, W.A., McClung, G. 1995. Metabolism of carbamothioateherbicide, EPTC, by Rhodococcus strain JE1 isolated from soil. Soil Sci. Society America J., 59: 1071-1077.

Barnes, H. 1959. Appa. Met. Oceanography, Part I Chemical, Allen and Unwin Ltd., London.

Boxall, A.B.A., Fogg, L.A., Blackwell, P.A., Kay, P., Pemberton, E.J., Croxford, A. 2004. Veterinary medicines in the environment. Rev. Environ. Contam. Toxicol., 180: 1-91.

Bray, R.H., Kurtz, L.T. 194). Determination of total, organic, and available forms of 
phosphorus in soils. Soil Sci., 59: 3945.

Crane, M., Watts, C., Boucard, T. 2006. Chronic aquatic environmental risks from exposure to human pharmaceuticals. Sci. Total Environ., 367: 23-41.

Ellis, M.B. 1976. More dematiaceous Hyphomycetes, Common Wealth Mycological Institute, Pub., Kew, Survey, England.

Fent, K., Weston, A.A., Caminada, D. 2006. Ecotoxicology of human pharmaceutical. Aquat. Toxicol., 76: 122-159.

Jackson, M.L. 1973. Soil Chemical Analysis, Prentice Hall of India Pvt. Ltd., New Delhi.

Larsson, D.G.J., De Pedro, C., Paxeus, N. 2007. Effluent from drug manufactures contains extremely high levels of pharmaceuticals. J. Hazard Mater, 148: 751-755.

Lindsay, W.C., Norvell, A. 1978. Proc. Soil Sci. Soc. Am., 42: 421-428.

Madhanraj, P., Manorajan, S., Nadimuthu, N., Panneerselvam, A. 2010. An investigation of the mycoflora in the sand dune soils of Tamilnadu coast, India. Adv. Appl. Sci. Res., 1: 160-167.

Madhanraj, P., Nadimuthu, N., Panneerselvam, A. 2011. Mycoecology in the soil of a Casuarina bioshield plantation along south east coast of India. Asian J. Pharm. Res. 1: 13-16.

Muthuvel, P., Udayasoorian, C. 1999. Soil, plant, water and agrochemical analysis,
Tamil Nadu Agricultural University, Coimbatore, India.

Raper, K.B., Thom, C. 1949. A manual penicillia Baltimore. The Williams and Wilkins Co., pp. 875.

Raper, K.B., Fennell, D.I. 1965. The genus Aspergillus., Baltimore: The Williams and Wilkins Co., pp. 686.

Sivakami, R., Arumugam, V., Premkishore, G. An analysis of zooplankton in a lake, Pudukkottai District, Tamil Nadu, India. Int. J. Curr. Microbiol. App. Sci., 4: 377-389.

Skladany, G.J., Metting, F.B. 1992. Bioremediation of contaminated soil. In: F.B. Metting ed., Soil Microbial Ecology, pp. 483-513.

Standfold, S., English, L. 1949. Agron. J., 41: 446-447.

Subbiah, B.V., Asija, G.L. 1956. A rapid method for estimation of available nitrogen in soil. Curr. Sci., 25: 258260.

Upadhyay, R.R., Bakhtavar, F., Ghaisarzadeh, M., Tilabi, J. 1978. Cocarcinogenic and irritant factors of Euphorbia esula L. latex. Tumori., 64: 99-102.

Von Arx, J.A. 1974. The genera of fungi sporulating in pure culture. A.R. Ganter Verlag, K.G. $2^{\text {nd }}$ edn., Vaduz Germany, pp. 375.

Walkley, A., Black, I.A. 1934. An experimentation the organic matter and proposed modification of the chromic acid titration method. Soil Sci., 37: 2938

\section{How to cite this article:}

Sugumar R., Anandha Raj. 2016. Studies on Growth Response of Fungi Using Antibiotic Ointments. Int.J.Curr.Microbiol.App.Sci. 5(3): 67-75. doi: http://dx.doi.org/10.20546/ijcmas.2016.503.010 